\section{Slik skal du veilede leger i spesialisering}

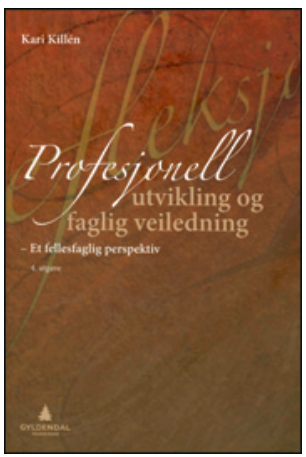

Kari Killén

Profesjonell utvikling og faglig veiledning

Et fellesfaglig perspektiv. 4. utg. 276 s. Oslo: Gyldendal Akademisk, 2012. Pris NOK 385 ISBN 978-82-05-42515-6

Løpende klinisk veiledning er nå en viktig del i all spesialistutdanning av leger og skal bidra til å sikre et høyt faglig nivå - både hva gjelder kunnskap, ferdigheter og holdninger. Kvaliteten av den personlige veiledningen gitt av en mer erfaren kollega er en avgjørende faktor for å oppnå dette. Det er i veiledningen av det løpende kliniske arbeidet at utdanningskandidaten skal integrere sine kliniske erfaringer med teori, og få hjelp til å mestre følelsesmessige og andre utfordringer i møte med pasienter, medarbeidere og pårørende. Målet er å utvikle evnen til en livslang refleksjon over eget arbeid, og en god relasjonskompetanse ved å bevisstgjøre den som blir veiledet, om egne holdninger, reaksjoner og livserfaringer som kan stå i veien for et fagligetisk samarbeid med pasientene. Det innebærer et stort ansvar å være klinisk veileder for unge kolleger. Denne boken vil kunne gjøre oppgaven lettere å mestre.

Forfatteren er en nestor innenfor området veiledning i Norge, og har selv en omfattende terapeutisk praksis og veiledningspraksis bak seg. Hun har også forsket på profesjonell veiledning innenfor helse- og sosialområdet. Boken gjennomsyres av at det er en erfaren kliniker som skriver, og som sjenerøst og reflektert deler sine erfaringer og kunnskaper med leseren. I noen korte kapitler gjennomgår hun fordeler og ulemper ved ulike hjelpemidler i veiledning og noen viktige problemer i gruppeveiledning.

Men det er den på samme tid jordnære og kritiske omtalen av veiledningsprosessen, dens praktiske og teoretiske side, som er gullet i denne teksten. Meget klokt relaterer hun alle sine erfaringer med denne prosessen og ulike grep man kan ta, til en modell for de fire fasene vi gjennomgår i den profesjonelle utviklingen: den selvsentrerte fasen, bære eller briste-fasen, forståelse uten evne til å handle-fasen og forståelse og evne til å handle-fasen. Både kjennetegn ved fasene, veiledningsmetodikk og utfordringer i hver enkelt fase er nyansert og innsiktsfullt beskrevet og belyst med gode, autentiske eksempler. Jeg fikk svært mange assosiasjoner til egen veiledning, og det er uproblematisk at de fleste eksemplene handler om kolleger fra andre helse- og sosialfag enn leger. Du verden hvor felles de er - utfordringene som ligger i å bistå til andres faglige vekst!

Måtte dette bli obligatorisk lesning for alle kolleger som blir satt til å fungere som kliniske veiledere (og psykoterapiveiledere) for leger i spesialisering. Bedre forebygging av utbrenthet enn god klinisk veiledning har vi neppe.

\section{Per Vaglum}

Avdeling for medisinsk atferdsforskning

Institutt for medisinske basalfag

Universitetet i Oslo

Oppgitte interessekonflikter: Anmelderen ga ut egen bok på Gyldendal Akademisk i 2009

\section{Flerstemte refleksjoner over veiledning}

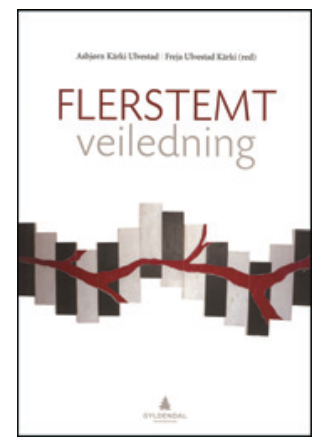

\author{
Asbjørn Kärki Ulvestad, \\ Freja Ulvestad Kärki, red. \\ Flerstemt veiledning \\ 374 s, tab, ill. Oslo: Gyldendal Akademisk, \\ 2012. Pris NOK 475 \\ ISBN 978-82-05-42389-3
}

Enda en «kokebok» om klinisk og psykoterapeutisk veiledning? Svaret er nei. Intensjonen til redaktørene, en psykolog og en sosionom, er i stedet å lage en fagbok som går «nærmere inn på noe av tenkningen innen feltet, ser på paradigmatiske forskjeller, stiller noen nærgående spørsmål i forhold til den sentrale plassen veiledningen har innenfor ulike sektorer, samt gir et innblikk i nyere forskning om veiledning».

Resultatet er blitt et flerstemt perspektiv på veiledning, i hovedsak innenfor helse- og sosialområdet, dels skrevet av redaktørene selv (nesten halvparten) og dels av 13 kolleger fra de fire fagfeltene psykologi, pedagogikk, sosiologi og filosofi. Overraskende nok har de ikke invitert inn noen erfarne veiledende leger, selv om klinisk og psykoterapeutisk veiledning er obligatorisk for alle leger i spesialisering.

Perspektivene veksler fra kritiske vurderinger av veiledningens positive og negative sider i dagens samfunn, til grundige drøftinger av ulike teoretiske modeller for veiledning og ulike veiledningsog læringsstiler. Bidragsyterne påpeker også betydningen av relasjonen mellom veileder og den som blir veiledet, for behandlingsresultat og kandidatens utvikling. Metoder for å skape tilstrekkelig trygghet til at kandidaten kan tore rapportere utfordringer og dermed komme videre, drøftes og eksemplifiseres.

Konsekvenser av maktforholdene i veiledningen, etiske dilemmaer og resultater av den sparsomme forskningen på veiledning gis også plass. Det samme gjør spørsmålet om hvordan og hvorvidt brukerne (klienten/familien/pasienten) også kan involveres i selve veiledningsprosessen. Endelig utvides perspektivet også til å gjelde hvordan veiledning kan brukes til å utvikle en «lærende organisasjon» og som ledelsesprinspipp i endringsutsatte virksomheter. Eksemplene er i stor grad generelle, og medisinske lesere må derfor selv finne relevansen i egen veiledningspraksis.

Forfatterne er engasjerte og kunnskapsrike og går ikke av veien for å ri noen egne kjepphester. Her og der dukker det opp tegn til en profesjonskonflikt i forhold til leger og det «medisinske» paradigmet. Med så mange forfattere har redaktørene vært vel permissive i forhold til gjentakelser, og teksten blir litt tung å lese sammenhengende. På den annen side står enkelte av kapitlene godt på egne bein og er noe man vil komme tilbake til. Gjentakelsene belyser også på en interessant måte hvordan standpunktet til et bestemt faglig spørsmål kan variere med utdanningsbakgrunn og om forfatteren har klinisk erfaring eller ikke.

Er denne boken interessant for leger? Dette er ganske riktig ingen innføringsbok i klinisk eller psykoterapeutisk veiledning, men erfarne kliniske og psykoterapeutiske veiledere kan likevel finne interessant og tankevekkende stoff som kan stimulere til viktig refleksjon over egen praksis. Boken vil også egne seg som bakgrunnsstoff for seminardiskusjoner om veiledning.

\section{Per Vaglum}

Avdeling for medisinsk atferdsvitenskap

Institutt for medisinske basalfag

Universitetet i Oslo

Oppgitte interessekonflikter: Anmelderen var en av to redaktører av læreboken i medisinske atferdsfag på Cappelen Akademisk. 